\title{
ARTICLE
}

\section{Indonesian Customary Law and European Colonialism: A Comparative Analysis on Adat Law}

\section{Zezen Zaenal Mutaqin*}

This paper argues that what Van Vollenhoven did in dealing with adat law was in fact part and parcel of the colonial policy to exploit the colony for the benefit of the Dutch and had nothing to do with being 'a good Samaritan' by saving 'the other' legal culture. What he did also was mainly triggered by what I refer to as cultural anxiety. His campaign to promote adat law was intensified by his fear of the rise of Islamic identity that would be used as a rebellious ideology by the people of Indonesia to fight against the Dutch. Furthermore, I argue that Van Vollenhoven's intellectual background, heavily influenced by European legal romanticism, had intensified his advocacy to promote adat law in Indonesia.

\section{Keywords}

Adat Law, Colonialism, NEl, Unification, Codification, Legal Pluralism, Romanticism, Cuturalist, Legal Positivism

\section{Introduction}

My first encounter with the complexity of the term 'adat mediated through Islamic

* Lecturer at the Faculty of Shari'a and Law, the State Islamic University ("UIN") Syarif Hidayatullah, Jakarta; Researcher at Lembaga Survei Indonesia ("LSI"), Jakarta. LL.B (UIN Jakarta), LL.M (Melbourne). The author may be contacted at: zmutaqin14@gmail.com / Address: Fakultas Syariah dan Hukum, UIN Jakarta, Jl. H. Djuanda No. 59 Ciputat. 
jurisprudence. As I was a student at pesantren (Islamic boarding school), studying Islamic jurisprudence was mandatory. For anyone who has learned this subject, the term 'adat must be very familiar. It is one of the many sources of Islamic law. The ultimate source of law in Islam, no doubt, is Al-Qur' an, a holly text from which Muslim jurists extract laws. Because Al-Quran does not contain any concrete rule and contains mainly general principles of value and morality, however the possibility for other sources of law to rise is open. Along with ijtihad (rational reasoning) and ijma (consensus), adat stands in Islamic jurisprudence as an important source of law so long as it does not contradict the primary source (Al-Qur' an). In this last regard, there is a common saying that: 'al- 'adah muhakamah' (adat could become law). ${ }^{1}$ The whole complexity of learning Islamic jurisprudence would, for me, later prove to be very important to the studies of adat in an Indonesian law context.

Analyzing adat law (adatrecht/hukum adat-in this paper the author will use the term 'adat law' instead of its Dutch term 'adatrecht') is not an easy task. Not only do we have to deal with a massive and long intellectual tradition made both by jurists and social scientists, but also should we account for a range of diverse systems of adat law. If we take a classification of adat laws, for example, made by Cornelis Van Vollenhoven, we have to deal with nineteen areas of law or 'jural communities' 2 such as adat Aceh, Minangkabau, Central and East Java, Sundanese (West Java), Minahasa, Moluccas, etc. ${ }^{3}$ Under these circumstances and in my opinion, if we strictly hold comparative legal and 'intellectual policy,' no single scholar, even if he is an Indonesian, can be an expert of adat law. He or she must be an expert of a particular adat law like, e.g., adat law of Aceh, Moluccas or Java. The reason being that no one can speak nineteen languages and understand all social and cultural aspects embedded in it. In this regard, I want to say that adat is a part of me and not 'the other.' However, it has also simultaneously become part of 'the other'.

Adat law is a kind of "Indonesian customary law." However, the matter is not as clear and distinct as that. Adat in Indonesian context always comes with an attribution; it can be adat Sunda, adat Jawa, adat Aceh, adat Minagkabau, adat Sulawesi, etc. There is no such thing called 'adat Indoensia.' The reason is because not only was adat as a legal discipline established by Dutch scholars long before Indonesia was created as a nationstate, but also because these adats essentially always take part in and integrate with

1 For details on the principle of Islamic Jurisprudence, see MD. Hashim Kamali, Principle of IsLamic JuRISPRUdence (1991).

2 This was a term translated from Dutch term 'rechtsgemeenschappen.' J. F. Holleman uses this term in his translation of Van Vollenhoven's works. See Van Vollenhoven on Indonesian AdAT LaW (J. F. Holleman ed., J. F. Holleman et al. trans., 1981).

3 Cornelis Van Vollenhoven, The Law Area, supra note 2, at 41-53. 
diverse ethnicities and 'nationalities' in the archipelago. Imagine if the Dutch never came to the archipelago, these ethnicities would probably have become independent nation-states with their own adat law. Born in West Java and thus being Sundanese, I have my own language which is totally different from, e.g., Padangese of Minangkabau in the West Sumatra, or Aceh language or even Bahasa Indonesia (Indonesian national united language). I have my own adat law (adat Sunda). Because of that, adat Aceh or Celebes or Minangkabau is 'the other' for me. So, in this regard, whether adat law is the other for me is a matter in question.

A more thought provoking question relates to the foreignness of adat law. Is adat law really Indonesian? Some scholars argue that, in fact, adat law was a Dutch creation. 4 It was invented by Dutch scholars; its courts were established by Dutch colonial administration; it was used by Dutch judges to make decisions and all material related to adat was, initially, written in Dutch. 5 It also, finally, becomes less important following the abandonment of all Dutch colonial officers from Indonesia in the late 1940s. However, in its development, adat would later regain its roles and influences on the contemporary Indonesian legal system especially on municipal law.

Realizing that the topic is very complex, my essay will only focus on adat law and its relation to the issue of legal unification. Indeed, adat law was 'created' as a response to the proposal of legal unification planned to be implemented in the colony. However, because the very origin of the term 'adat' and its initial discovery, discussing adat and its relation with the colonial policy on Islam in the Netherland East Indie ("NEI") is unavoidable.

In this context, the author should uncover the reason behind choosing this topic. The debate about legal unification has recently gained intense concern in comparative law. The debate relates not merely to the controversy of legal unification (mainly in the context of merging European countries), but also gone deeper to philosophical and methodical questions: how should I face 'the other?'; is comparative law dedicated to finding sameness and become a tool of legal unification?; are there any common structures lying on the bottom of legal differences?6 In this debate, two schools of thought or, weltanschauungs, stand in opposition to one another. The positivist school is a proponent of legal unification; positivists believe that comparative law should be

4 Daniel S. Lev, Legal Evolution and Political Authority in Indonesia 20 (2000). See also Peter Burn, The Leiden Legacy: Concepts of Law in Indonesia (2004); Harry J. Benda, The Crescent and The Rising Sun 67 (1958); M.A. Jaspan, In Quest of New Law: the Perplexity of Legal Syncretism in Indonesia, 7 ComP. STUD. IN Soc'Y \& HIST. 252 (1965).

5 Id.

6 Pierre Legrand, The Same and the Different, in Comparative Legal STUdies: Traditions and Transitions 240 (Pierre Legrand \& Roderick Munday eds., 2003). 
dedicated to unearth similarities for the sake of legal unification. There is a common structure lying at the bottom of national-legal differences, the argument goes, which allows for the law to be transplanted from one culture to another.7 On the opposite side, the culturalist school of thought argues that comparative law is meant to celebrate diversity and differences. It views legal unification as impossible, essentially and not politically, and considers that comparative law should be dedicated to understanding differences in the other without any pretention to reduce them to be part of 'us' as well as to respect the other. It views the fusion of 'I' and 'the other' as impossible and consequently, transplanting law is not realistic. 8

Seeing it in the light of history, the author realizes that everything is in 'eternal recurrence.' What took place in the NEI and the Dutch in the eighteenth century look similar, if not exactly the same, to what still happen recently in the European context. Van Vollenhoven who was a fighter for legal pluralism and anti-unification of the NEI was like Pierre Legrand and his colleagues who joined the culturalist school in the European context of today, challenging the idea of European legal unification. However, the contemporary fighters of legal pluralism will only be discussed slightly here. My essay will deal mainly with Van Vollenhoven. The author will illuminate his thought in light of the contemporary debate on legal unification in comparative law.

This paper will argue that what Van Vollenhoven did, in fact, was a part and parcel of the European colonial policy to exploit the colony for the Dutch benefit, and had nothing to do with being 'a good Samaritan' by saving 'the other' legal culture. What he did was also mainly triggered by what I refer to as cultural anxiety. His campaign to promote adat law was intensified by his fear of the rising Islamic identity that would be used as a rebellious ideology by the people of NEI to fight against the Dutch. Furthermore, I will argue that this factor met with the influence of European legal romanticism in Van Vollenhoven's intellectual background.

By doing this, the author wants to put Van Vollenhoven's ideas on adat law in the line of Hurgronje's main purpose of inventing and promoting adat law for Indonesian people. But more than that, I also want to trace the very European origin of adat law in Van Vollenhoven's works.

To do that, this paper will firstly discuss the colonial context and the emergence of adat law in the NEI. In this part, the author will engage in a historical analysis in relation to the rise of adat law as an established discipline. It is important to trace the social and

7 For details on this school, see Konrad Zweigert \& Hein KotZ, An Introduction to Comparative Law 1-62 (Tony Weir trans., 3rd ed., 1998).

8 This may be found everywhere in Legrand's essays and other culturalist scholars. See, e.g., Pierre Legrand, The Impossibility of 'Legal Transplants', 4 MAASTRICHT J. EUR. \& COMP. L. 111 (1997); On the Singularity of Law, 47 HaRV. INT'L L. J. 517 (2006). For details on the culturalist stance, see supra note 6, Essays. 
political circumstances behind the rise of adat. The role of Dutch legal scholars in 'discovering' or 'inventing' adat law will be discussed with much attention and will mainly be devoted to two Dutch scholars, Christian Snouck Hurgronje and Cornelis Van Vollenhoven. Hurgronje in my essay is important because he was the first Dutch scholar that systematically used the term adat law. By discussing Hurgronje we can also reveal ideological dimensions of adat law.

The second part of this essay will deal with a genealogical tracing of adat law in the European legal traditions. The author will present the influence of the historic debate of codification in Germany between Anton Thibaut and Carl Von Savigny to the formation of adat law theory of Van Vollenhoven. Looking into the European origin of adat law will clarify the influence of European legal romanticism in Van Vollenhoven's intellectual background. It will also clarify that adat law was the Dutch law and a Dutch creation. Thus, in this chapter, I will attempt to trace the genealogy of adat law in the land where Van Vollenhoven lived, received legal education, learnt history and formulated his theory.

\section{Dutch Legal Scholars and Adat Law}

\section{A. Hurgronje: taming Islam, promoting Adat}

If it was about a transaction, then it happened in an uneven transactional relationship. It was actually a representation. It was also about the civilized West that appropriated the East. This was about the West that invented and created the image of the East. It took place in the age of colonialism.

What will be discussed here is not mainly colonialism in term of geographical and political occupation of the third world by Western countries, but rather the role of scholars in collaboration with their generals and colonial administrations to represent, discover or even invent the East as an object of studies. Here, we will deal with the scholarly tradition of orientalism as brilliantly explained by Edward Said. ${ }^{9}$ But instead of dealing with the French or British orientalism as Said did in his book, the author will try to deal with the Dutch orientalism, describing the role of the Dutch scholars in discovering or inventing adat law in the NEI. More specifically, here, the role of a founding father of adat law, Christian Snouck Hurgronje in the colonial administration will be uncovered. 10

9 EdWARD SAID, ORIENTALISM (1978).

10 Christian S. Hurgronje, The Achehnese (A. W. S. O' Sullivan trans., 2008). 
Hurgronje came to Batavia (Jakarta) on May 11, 1889. His arrival was burdened by a hope that he could fill the gap of colonial policy on Islam there. Until his arrival, Dutch Islamic policy mainly relied on the combination of fears and misconceptions on Islam in Indonesia. 11 The Dutch, for example, apprehended Islam as a hierarchical, strict, structured religion with the Turkish Caliph at its top. 12 For the Dutch, local sultanates in the archipelago were assumed as a part of the great power of Turkish Caliph. The rebellious resistances in the archipelago which took place in Java (Java war 1825-1830), Aceh (Aceh War 1873-1903), Minangkabau of the West Sumatra (Padri war 1821-1827), and Banten (1888) were also seen by the Dutch as Islamic-inspired rebellions which connected to the center of Islamic empire in Turkey.13 Thus, for the Dutch, like for other European powers including French and British at the moment, Islam was the only potential threat for their domination. 14

In encountering this threat, the Dutch believed that the elimination of Islam from the archipelago was the only solution. Groups of missionary, both Catholic and Protestant, were sent to the archipelago to operate under the government sponsor. The pilgrim to Mecca (Hajj) for people from the archipelago was also restricted. This practice of pilgrim was seen as the main axis that connected Islam in the archipelago with its center in the Middle East.15 Islam was regarded as a real fanatic and organized enemy against the Dutch in its colony.

As an expert of Semitic languages and experienced living in Mecca, the heart of Islamic religion, his arrival was significant indeed. His appointment as an Advisor of Arabian and Native Affairs for the Dutch government had to be accomplished by visiting the colony. He did not come with nothing, but certainly he was equipped by the networks and knowledge of the native cultures as the result of his spending one year lived in Mecca to research the life of people from the NIE who settled in the hearth of Islamic religion. He went to Mecca, where he pretended to be a Muslim with a Muslim name Abdul Gaffar, 16 as an expert of Islam following the controversy of the pilgrim restriction by the Dutch government in the early nineteenth century. His experience of living in Arabia and Mecca for one year from 1884 to 1885 can be known from his book,

11 Harry J. Benda, Christian Snouck Hurgronje and the Foundation of Dutch Islamic Policy in Indonesia, 30 JouRNAL OF ModERn History 338-347 (1958).

12 Id. at 338-339.

13 AqiB Suminto, Politik Islam Hindia Belanda 9-10 (1985).

14 Supra note 9 , at $73-78$.

15 Supra note 11.

16 Please be sure that Mecca is a holly place for Muslims in which non-Muslims are not allowed to enter. Because of that Hurgronje converted to Islam before entering Mecca. In regard to whether his conversion was only a strategy or genuine, nobody knows. I just belong to the opinion saying that his conversion was only a strategy to get access to Mecca. 
Mekka in the Latter Part of the 19th Century.17 This book does not deal with Mecca as a holly city or about pilgrimage at first hand, but about Jawi people 18 who settled in Mecca where the colonial government believed they were the mastermind of rebellious resistances in the archipelago. Mekka mainly deals with the influence of 'Mohammedan fanaticism' upon the life of Jawi people. The last chapter of his book is devoted specially for discussing the life, customs and learning of the 'Jawah'(Hurgronje used 'Jawah' term instead of 'Jawi' with the same meaning) people in the holly city. In this chapter he identified who were the most influential Muslim scholars from Jawah who settled in Mecca and their relation to the idea of Pan-Islamism in the archipelago. ${ }^{19}$ By living in Mecca, Hurgronje had tried to trace the genealogy of rebellious Islamic ideology in the archipelago and learnt how to pacify it.

His experience of living in Mecca with the Jawi community gave him an extensive connection to the most respected ulamas (Muslim scholars) in Java in which it would later be very useful for his field of work. This connection was a key element to penetrate in the heart of people. When he arrived in Java, he personally knew almost all respected ulama of Jawah who settled in Mecca like Nawawi Al-Bantani of Banten, Khatib Sambas of Borneo, Abdul Gabi Bima of Sumbawa, Said Usman of Batavia, Hasan Mustapa of West Java, Abu Bakar Djajadiningrat of Banten (his main native informant in Mecca especially after Hurgronje left the holly city in 1885) and many more.20 He even closely knew some of the leaders of Banten rebel, which took place eleven months prior to his arrival like Muhammad Qasid, Marzuki and Abdul Karim, the ulamas who for several years lived in Mecca and studied to Nawawi Al-Bantani.21

His relationship with Hasan Mustapa was a special one. Hasan Mustapa had become his main native informant and guide to penetrate both to people in Java and in Aceh. Hurgronje knew Hasan Mustapa at the first time in Mecca in 1884. After returning from Mecca, Hasan became a penghulu22 in Garut, West Java. In 1893 Hasan Mustapa was appointed as chief penghulu in Kuta Raja, Aceh. This position was designed intentionally by Hurgronje to help him connect with local leaders in Aceh. At the time of Hasan Mustapa's appointment as penghulu in Kuta Raja, the Aceh war was

17 Christian S. Hurgronje, Mekka in the Latter Part of the 19'7 Century, Daily Life, Customs and Learning of THE Muslims of the East-Indian-Archipelago (J. H. Monahan trans., 1931).

18 Id. at 262-280. The term 'Jawi' was used by Mecca residents who came from Indonesian archipelago. This indicated that the first settlers from the archipelago were mainly from Java (Jawa).

19 Id.

20 Id.

21 Supra note 17, at 274. See also Michael F. Laffan, Islamic Nationhood and Colonial Indonesia: the Umma Below THE WINDS 88 (2003).

22 It was a salaried position for Islamic affairs funded by the Office for Native and Arabic Affair of the Dutch Colonial Government. This position is still retained by the Indonesian Government. 
entering its fifteenth years. 23 This was the only region remaining to be conquered by the Dutch. And Hurgronje was the one who was responsible to give the best advice for the colonial government. By the assistance of Hasan Mustapa, Hurgronje toured across Aceh and lived there for one year from 1891 to $1892 .{ }^{24}$ As he did in Mecca, in Aceh, Hurgronje was occupied by interviewing local ulamas, made ethnographic notes, analyzing landscapes, taking photographs, and observing local customs and life for his scholarly work. He was busy gathering raw materials to study Aceh and, consequently, he cleared obstacles and paved the way for the Netherland troops to conquer it.

De Atjehers (The Achehnese) is Hurgronje's magnum opus. 25 This book is not only impressive because of its scholarly achievement, but also because of its practical usefulness for the Dutch colonial government. This is an excellent example of how knowledge was transformed to power during colonialism as well as of an implicit nature of imperialism in orientalists' scholarly works. His introduction in The Achehnese openly declares that the purpose of his massive book was to provide "the foresight and local knowledge necessary to enable officers with their small detachment of troops to march tens of miles a day over very hilly ground, often pathless, through forest, swamp and riverbed to reach some hidden destination" in the guerilla war against the Acehnese. 26 He fully realized that the only way to subjugate the most rebellious region in Indonesia was by knowing it in a full detail. He said that: "Holland has been engaged in war against Aceh for a period which has extended to about thirty years without having led to the subjugation of native kingdom...due to faulty policy or to ignorance or to faithlessness." 27

For our purposes, this book is also really essential because in this book, the term adat law is repeatedly used by Hurgronje. From a purely scholarly point of view, this masterpiece with more than 800 pages in two volumes is an impressive achievement in the field of adat law. ${ }^{28}$ This is also unique because through its passages and paragraphs we can see the un-separated organic-engagement of adat law with culture, politics, economy and religion. By simply looking into the table of content, we will know that there is no single chapter of his book devoted separately to discuss adat law. However, by diving into its subtle discussion of, for example, Aceh form of governments,

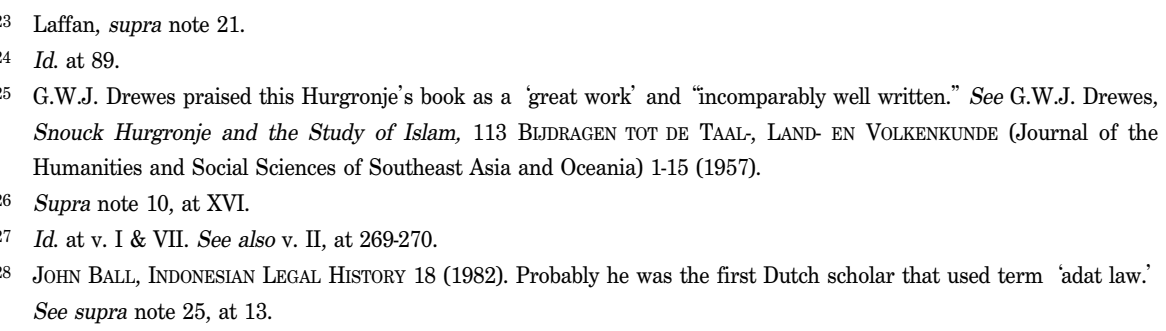


calendars, navigations, domestic life and law and religion, we will become aware that the ultimate goal of his book is to define adat law. Moreover, adat law in Hurgronje's book cannot be separated from 'Mohammedan law' (Islamic law). Indeed, in my opinion, adat law was invented by Hurgronje almost unintentionally while he was discussing the influence of Mohammedan law upon "the obstinate resistance of the Achehnese to Dutch rule." 29

The basic idea of Hurgronje's account on adat law, as discussed in his book, is that while the majority of Aceh people were Muslim, only little of their aspects of life were influenced or inspired by Islamic law. 'The transplantation' of Islamic law, to borrow Alan Watson's terminology, 30 concomitant with the spread of Islam into the land of Aceh gained only minor success if not entirely failed. Almost all aspect of their life, from the form of government to divorce and marriage laws, were mainly still bound by local costmary laws, which called adat by the Acehnese. 31 Thus, as long as it related to the guidance of life, two categories can be made: adat and syari'a-Hurgronje sometimes uses adat vs. hukom in his book. Adat is the rules that are pursuant to local custom and traditions, while syari' at is laws that are founded upon Al-Qur' an and divine revelation. 32 Hurgronje notes that this is not a sui generis of Aceh phenomenon, but it is a common feature of every Muslim country. 33 In addition, contrary to the common assumption saying that hukom and adat should take place side by side without conflict, Hurgronje explains that in reality both adat and hukom are in conflict with one another. ${ }^{34}$

By acknowledging adat as an element that is, to some extent, different and even in conflict with Islamic law, Hurgronje confidently believed that he found a basic pattern to formulate Islamic policy for the colonial government. Harry J. Benda notes that Hurgronje was the first Dutch scholar who realized the usefulness and importance of adat law to reduce or impose the influence of Islamic law to its believers in Indonesia.35 Benda adds that Hurgronje's recommendation for the Dutch colonial government on Islam can be summarized into three points. ${ }^{36}$ First, contrary to the common assumption among the Dutch at that time, the nature of Islam in Indonesia can be divided into the religious and political Islam. Toward religious Islam, nothing to be worried at all since this Islam was private in nature and related mainly to the ritual aspects of Islam.

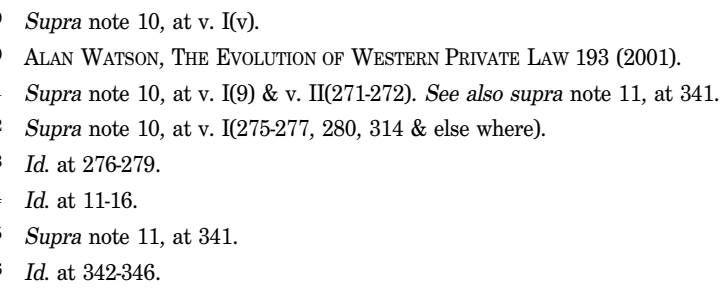


Hurgronje counseled toleration in dealing with this kind of Islam. Hurgronje for this reason recommended that the pilgrim to Mecca (Haj) should not be restricted at all. In dealing with the political character of Islam, however, Hurgronje, without a doubt, recommended force and suppression to handle it. Benda calls this a "twin policy of tolerance and vigilance." Second, this twin policy should go in association with the support and encouragement of adat institutions both in Java and in the outer Islands like in Aceh and West Sumatra. This policy later would be manifested, for example, in a colonial regulation where if the conflict of law took place between Islamic law and adat law, the latter would prevail.37 Third, for the long-term policy, the defeat of Islam could totally be achieved by promoting what he called the policy of association and emancipation. This policy was based on an assumption that for the long term, neither Islam nor adat would be preferred as the foundation for the transformation of modern Indonesia. The future of modern Indonesia should be relied on Western (Dutch) culture and civilization. Indonesia, in this policy, was regarded as a 'younger brother' that would have advice and help from her 'elder brother,' the Dutch. Indonesia should be part of Western civilized nations in the long term. To achieve this, Hurgronje proposed scholarship of education policy for elite local aristocracies. For Hurgronje, education was the most effective way to integrate Indonesia into western culture. ${ }^{38}$

\section{B. Van Vollenhoven and Legal Pluralism}

If Hurgronje was heavily illuminated by the 'episteme' of the nineteenth century orientalism, in which his personal interest on Islamic studies met with the political interest of the Dutch generals to conquer its Muslim colony, in Van Vollenhoven's works we can see the trace of European legal romanticism.

When Van Vollenhoven held a chair of Adat Law professor in Leiden in 1901, adat law was in the beginning of its scientific exploration. Hurgronje was considered by Van Vollenhoven as a scholar with an artistic gift that expressed his idea as brilliantly as Emille Zola. ${ }^{39}$ Along with G.A. Wilken,40 an expert on ethnological jurisprudence of Malay society, Hurgronje became the corner stone for Van Vollenhoven's works on adat law. The influence of his predecessors, especially Hurgronje, could be seen from the political edge of Van Vollenhoven scientific work on adat law. While expressing his disappointment for the lack of interest on adat law among Dutch lawyers, e.g., Van

\footnotetext{
DANiEl S. Lev, IsLAmic CouRTS IN INDONESIA 10 (1972). See also supra note 13, at 43.

38 For an account of association policy, see supra note 13, at 38-63; Laffan, supra note 21, at 90-94.

9 Van Vollenhoven, Study of Adat Law, supra note 2, at 27.

40 Id. Wilken was the former colonial officer in NEI who later became an expert of Malay ethnology. However, he died unexpectedly when he was 44 years old in 1891.
} 
Vollenhoven said that: "Islamic law and Western law are known to be on the watch for suitable opportunities to swallow an even larger 'slice' of indigenous law." 41 For Van Vollenhoven, studying adat law was very important not only because of a practical reason for every colonial officer, but also for an ideological reason. In other part, he repeated his concern on the threat of Islamic Law. After discussing in detail adat law of Aceh, he concluded his chapter by asking whether or not European law could stand to replace adat law of Aceh. For this question he undoubtedly argued that "proven social needs and demand" for that "have not been proved at all" and "the introduction of the first few chapters of our law of property would do serious harm" to adat law. In the end, he said that: "The destruction of adat law will not pave the way for our codified law, but for social chaos and Islam." 42

Mishandling of adat law that would ultimately lead to its destruction, for Van Vollenhoven, took place primarily because of the lack of knowledge of adat law. For quite a long time adat law was seen as similar to, or part of Islamic law merely because the majority of Indonesian people were Muslim. The chair of Colonial Law and Native People of the NEI at Leiden University was named as the chair of Mohammedaansch recht due to this misunderstanding. Only after Van Vollenhoven accepted this chair in 1902 was the name changed to Adatrecht of the Netherland East Indies.43 L.W.C. van den Berg, the Dutch Government adviser on Oriental languages and Islamic law from 1878 to 1887 and a professor at Delft, according to Van Vollenhoven, was the one who was responsible for this misunderstanding. His theory of "reception in complex" of Islamic law by Muslims, Hindu law by Hindus as well as Christian law by Christians had became the mainstream opinion within Dutch legal scholars. 44

According to this doctrine, "the law of the Native is conditioned by their religion until the contrary is proved" because by accepting a religion they also "virtually accept religious law." 45 Thus, if the contrary was proved for one or more subjects, it would be regarded simply as a 'deviations' from religious law.46 Thanks to Hurgronje who had criticized and ruined this doctrine by proving that despite the fact that the majority of people of the NEI were Muslim, only little of their life was affected by Islamic law, as discuss above.

Moreover, the real problem of misunderstanding, according to Van Vollenhoven, was deeply rooted in the circumstance of the Dutch legal education. Legal education did

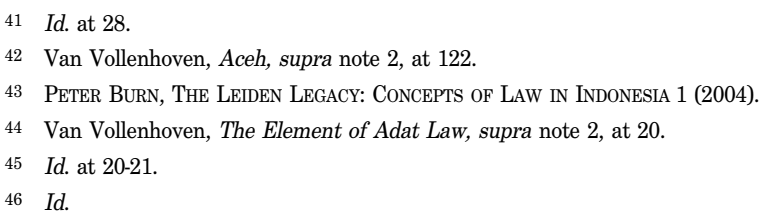


not pay attention to the historical perspective of law while too much paying attention to "the two legal system" (Today's Dutch law and the private law of Justinian). By ignoring this aspect, Dutch lawyers were not aware of particular and historical phenomenon of other legal systems that developed according to certain rules. ${ }^{47}$ In addition, the feeling of superiority of the Western culture and its ethnocentrism during the age of imperialism made their ignorance to "the lesser breeds without the law" even deeper among them." 48 Adat law was ignored because of this a-historical legal tradition among Dutch scholars as well as its ethnocentrism.

Thus, along with his concern on Islamic law, the flavor of European legal romanticism is strongly felt in his work. He, unlike his Dutch colleagues who supported the idea of 'transplanting' European law into its colony, insisted to preserve and support adat law. In the last paragraph of adat law of Aceh, he says:

No one wants a Western form of judicial process. What these people therefore need is not premature application of European law and procedure, but a thorough investigation of all their adat law, followed by a gradual process in which some parts are developed and supplemented, and other eliminated. 49

These two reasons, the concern on the threat of Islamic law 50 and the influence of European romanticism, in my opinion, were the main foundation of Van Vollenhoven's opposition against the idea of unification of civil code for all populations (both native and westerners) who lived in the NEI that arose in the late nineteenth century.

Before we continue to discuss the debate on unification of the civil code and knowing Van Vollenhoven's response to it, the author need to mention briefly the sociopolitical situation in the colony at that moment. This could be the right way to understand why Van Vollenhoven tended to admire and support the native interest despite the fact that he was part of the colonial government.

An indebted feeling to its colony highlighted the last four decades of Dutch colonialism in Indonesia. However, it was not until C. Th. Van Deventer published his essay in De Gids, the most important periodical at the time, that this debt of honor became a political movement. Van Deventer, according to Peter Burn, in his essay, "A Debt of Honor" argued that after long period of exploitation and extraction of the colony, the Kingdom of Netherlands in Europe had moral and financial obligation to

47 Id. at 28-29.

48 C. Fasseur, Colonial Dilemma, Van Vollenhoven and the Struggle of between Adat Law and Western Law in Indonesia, in The Revival of Tradition in Indonesian Politics: the Deployment of Adat from Colonialism to INDIGENISM 54 (Jamie S. Davidson and David Henley eds., 2007).

49 Van Vollenhoven, Aceh, supra note 2, at 122.

50 Daniel S. Lev, Colonial Law and Genesis of Indonesian State, 40 INDONESIA 57-74 (1985). 
develop his colony. 51 In his essay, Burn calculated that Holland had unjustly extracted around 187 million guilders from its colony between 1867 and 1877.52 Without reformation of social welfare, economic and social aspects, disaster in the colony could not be prevented. This liberal humanitarian vision finally gained wide political recognition. A new 'Christian Cabinet' under the leadership of Abraham Kuyper had a commitment to reform the colonial policy. Ultimately, on September 17, 1901, the Queen of the Netherlands announced her commitment to modernize and develop the NEI under the umbrella of what later became well known as the Ethical Policy. ${ }^{53}$

The author would note that though a liberal humanitarian movement initiated this ethical policy, the spirit of Christian missionary only transformed it to be a state policy. Abraham Kuyper's confessional ministry, in this regard, made a pledge that:

As a Christian state, Holland is obliged to suffuse its entire policy with a conviction of moral responsibility to the people of these territories, and in particular to improve the legal position of native Christians and give more tangible support to the Christian Missions. 54

In the 'milieu' of paying debt of honor to the colony, in 1904, a proposal for civil code unification was submitted to parliament by Idenburg, Ministry of Colony.55 The Dutch colonial legal policy until then was marked by legal pluralism. Hooker notes that the process of legal conflict during colonialism, marked Indonesian legal history due to the fact that since the earliest day of the Dutch presence in the archipelago, judicial administration was designed to be plural in nature. The Dutch established different tribunals for Europeans and Natives. The NEI constitution of 1847 classified the population of the archipelago into European and Native. The Chinese, Arab, and Indian inhabitants were included to the Native group until 1920. Article 163 of the 1920 amendment of the NEI constitution slightly changed the structure of legal grouping by separating the foreign Orientals (Chinese, Arab and Indian) from Native and enforced their own law. Adat law and the particular aspects of Islamic law were in force for the Native, while for Europeans Dutch law was in force.56 Under these circumstances, the

Supra note 43, at 1 . For an extensive reference in Indonesian language dealing with this specific issue, see generally R. Supomo \& R. Djokosutono, Sejarah Politik Hukum Adat (The Political Histroy of Adat) 1848-1928, v. 2 (1954).

52 H. W. J. Sonius, Introduction, supra note 2, at XXXIII.

53 Supra note 44, at 1. See also supra note 52, at XXIX. For further discussions on ethical policy, see A. VANDENBOsCH, The Dutch East Indies, Its Problems, Government and Politics 63-73 (1944).

54 H. W. J. Sonius, Introduction, supra note 2, at XXIX.

55 Id. at XXXIV.

56 For a brief but good description on legal pluralism in Indonesia, see M. B. HookeR, A CONCISE LEGAL HisTORY OF South-EAST AsIa 187-213 (1978). 
proposal of a unified civil code for all elements of the population was submitted to parliament.

In response to this proposal, two different reasons had emerged, both from liberal and conservative groups, to support this proposal. The first argument was based purely on a practical reason. Through unification, colonialism would have a more efficient tool for commerce and other economic business or even exploitation. 57 It also meant efficiency since a different tribunal would no longer be needed. The second and most important argument in supporting this bill came from liberal groups. Basically, the liberals argued that the only way to modernize the colony was by integrating it into European-Western system. Thus by this unification, Indonesians would be drawn into the "modern world of commerce and civil relation." 58 In this case, Van Deventer was one of the most important proponents of the unified and westernized civil code proposal. In his article that was published in 1905 in De Gids, Van Deventer said that although the nature of things might necessitate legal diversity, such diversity was not desirable.59 This position would later lead to his opposition against Van Vollenhoven.

Behind all the argument of the civil law codification laid the assumption of positivism in which the law was seen as the creation of a legislator and derived its validity from the will of parliament. Because the NEI was a sovereign territorial State, legal unification which could be enforced for all the populations was necessary. 60

This argument was really convincing for many lawyers but not for Van Vollenhoven. It ignored the very basic plural characteristic of cultures, languages as well as legal systems of the NEI. "The fact of life" 61 in the colony in which Java, Sumatra, Moluccas had their own kings, institutions, laws, languages and cultures simply could not be easily replaced by a Dutch-made unified civil code. Even if the codification was preferred, it must reflect the cultural characteristics of the people. Van Vollenhoven who called this proposal the 'lawyers' law' insisted that the codified civil law simply be a dead letter regulation. ${ }^{2}$ He pointed out that Article 131 (4) of the 1854 NEI constitution that allowed a voluntary submission of the Natives to the European law in case of commercial transactions and contracts did not attract the Natives to take advantage of this opportunity. In West Borneo, he added, where the courts were competent to judge almost all matters of dispute, no single Dayak people came to the

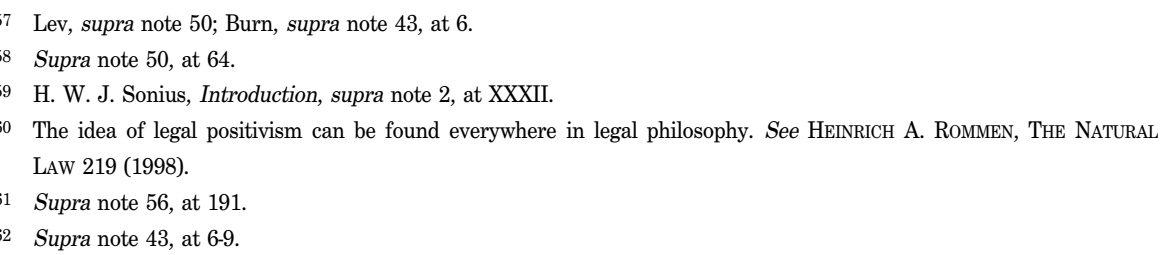


court to resolve their dispute.63 They preferred to resolve their case through local customary law (adat law). Thus, "the fact of life" showed that adat law as living law was more effective and forceful in practice than an imported Dutch-made law.

By making law that grows in a particular culture as a primary to the hand-made law, Van Vollenhoven, as Hooker notes, has shifted the definition of law from a formal requirement to a sociological definition. Cultural contents and the functionality of law, moreover, became a more important element of law than its legal formality. ${ }^{64}$

In the same year of Van Deventer's publication, Van Vollenhoven published his article, "No Lawyers' Law for the Indonesian,"65 Criticizing the codification, he illustrated a proposal for 'lawyers' law,' as a dominating Roman law that would force all indigenous adat laws to submerge. He then argued that the "fact of life," the 'kaleidoscopic' Indonesian legal situation did not fit with the objective of the proposal.66 The proponents of the proposal, in response to Van Vollehvoven' criticism, modified the bill in favor of the indigenous laws through an amendment made by Van Idsinga. 67 However, until the end of the story, due to the convincing and influential arguments of Van Vollenhoven in defending adat law, the proposal was never put into operation in the colony. 68

\section{The European Origin of Adat and the Colonial Policy}

\section{A. Historical Overview}

Unlike Hurgronje who spent more than ten years living in Indonesia to investigate his object study, Van Vollenhoven made only two short trips to Indonesia (in 1907 and 1923) during his life. Even though Daniel S. Lev was worried that Van Vollenhoven "may have not fully understood the underground social and political tension of the racial mix" 69 in Indonesia due to the lack of living experience there, no one would put to doubt his dedication in studying adat law. He spent his entire intellectual life to read, 
analyze, summarize and write on adat law based on available data that for decades were gathered in Leiden University by colonial officers, scholars and travelers. Van Vollenhoven, as Van Ossenbruggen has noted, has elevated adat law into a scientific position with a fascinating influence both to the intellectual milieu and political situation at his time. ${ }^{70}$

However, for the author, this fact is really interesting. The spatial distance separated him from the reality of actual adat in the NEI, has led me to a few questions: is adat law Indonesian?; did Van Vollenhoven elevate adat to a scientific position for the sake of Indonesian people or for the interests of his colonial government or even simply for the sake of intellectual satisfaction? Despite all the motives behind it, several things are clear that the formulation of adat law took place: in the Netherlands; in the background of intellectual milieu of European legal tradition; in Dutch universities; and presented mainly for Netherland audiences. Even though in the later time some Indonesian legal scholars or Dutch scholars who settled in Indonesia like Ter Haar participated in formulation of adat law discourses, 71 native Indonesians remained in a peripheral position and mainly only became a spectators or even objects of adat law study. Thus, it is then necessary to look into European legal history to see adat law. This historicity influenced the way Van Vollenhoven analyzed his object study and formulated his own theory of adat law.

To begin with, historical precedent that influenced so much the formulation of adat law theory took place throughout Europe as the consequence of the Enlightenment in the late eighteenth century. Enlightenment brought about a new way of seeing reality in which human beings no longer relied on the authority of a supernatural reality (God). Reason became the main anchor for all aspects of human life. Politics, economics, philosophy, culture, religion and also law became the object of human rational criticism. The effect of Enlightenment on law was also fundamental. Ecclesiastical laws were replaced by natural law before finally reached its form of positivism. Roman law which during the Middle Age spread throughout Europe, had developed to be more distinctive from its original root. It was also more diverse in its uniqueness due to the different circumstances and cultures where it grew. The way of usus modernus Pandectarum (articulation/interpretation of the Roman law based on local-customary law) led to the direction of creating new legal institutions and formulating a more systematic law.72 One of the most important products of the enlightenment was legal

70 H. W. J. Sonius, Introduction, supra note 2, at L.

71 Ter Haar was Van Vollenhoven's disciple who lived in Indonesia and taught at Law School in Batavia (Jakarta). See B. Ter HaAR, AdAT LAW IN Indonesia (George C.O. Haas \& Margaret Hordyk trans., 1948).

72 Konrad Zweigert \& Hein Kotz, An Introduction to Comparative LaW 133-139 (Tony Weir trans., 1977). 
codification. Codification began from an assumption that the diverse unmanageable ancient laws could be replaced by a comprehensive and intentionally planned legislation under the auspices of reason.73 Bavarian Code, Codex Maximilianeus Bavaricus Civilis, appeared in 1756, while Prussia produced its own code, Preussisches Allgemeines Landrecht with its 19,194 paragraphs, 40 years later in 1794 after nearly a century debate and preparation. ${ }^{74}$ The codification of the French Civil code, known as the Napoleon Code in 1804, was the landmark of the codification movement in this era. This was a revolutionary effort to reconfigure post-Revolutionary French society through a comprehensive revision of the law. 75

However, towards the early nineteenth century, the path of rational optimism that was generated by the Enlightenment was struck by a new wave of pessimism to the power of reason. Isaiah Berlin called it the counter-Enlightenment movement in which he identified Giambatistta Vico, J.G. Hamann and J.G. Herder as the three main critics of Enlightenment. ${ }^{76}$ The other author identified three distinct strains of critics to the Enlightenment: Conservatism (included here Historical School of Jurisprudence), German Romanticism and French Revolutionaries. ${ }^{77}$ Emphasizing different flaws in the Enlightenment, all these critics were bound by a similarity, i.e., the return of non-reason elements into the stage of European intellectual landscape. This Romantic movement came along with a strong believe to 'irrational power' of human life as can be seen from concepts that they utilized like 'people,' 'development,' 'soul,' 'feeling,' and 'sensibility.' 78

\section{B. German Tradition of Counter-Enlightenment}

It was Anton Thibaut, a professor at Heidelberg, who enthusiastically proposed the idea of civil code unification for Germany. ${ }^{79}$ In 1814, illuminated by the spirit of the Enlightenment project, Thibaut published his leaflet entitled, On the Necessity for a Common Civil Law for Germany with optimism that the moment was the right time to unite all small German states. 80 A year earlier, in 1813, the Rhine German Confederation, the confederation of thirty-nine German princes under Napoleon, where it had lasted since 1806, disintegrated into independent States. This was a good

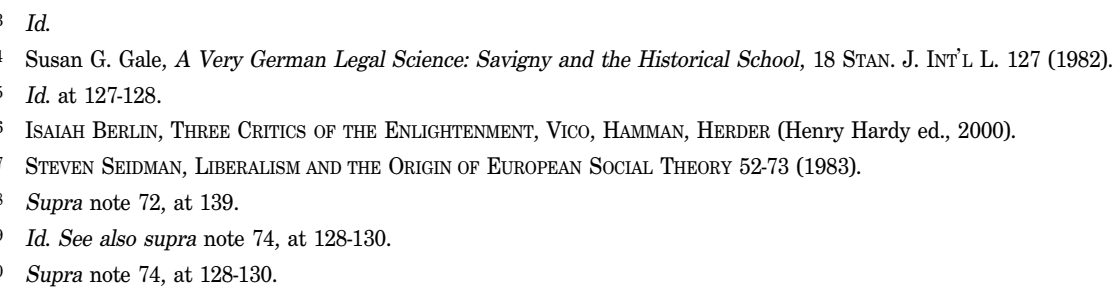


opportunity, Thibaut saw, to bring about a political union by means of a "simple national codification, developed in German Spirit with German strength." 81 The French Napoleon civil code should be replaced by a common civil law of Germany.

Similar to what would be carried out by Van Vollenhoven around 50 years afterwards in Holland in response to the proposal of civil code unification of the NEI, Carl Von Savigny opposed Thibaut's proposal of German civil code unification. While Thibaut was in the line of Enlightenment tradition, Savigny carried on the tradition of the counter-Enlightenment. Savigny published "On the Vocation of Our Time for Legislation and Legal Science(Vom Beruf Unserer Zeit Fur Gesetzgebung Und Rechtswissenschaft 1814)" only a few months after Thibaut's pamphlet appeared to the public. 82 This was Savigny's immediate response to the proposal of codification. However, as Susan G. Gale has mentioned, On the Vocation was not merely polemical response to the Thibaut's ideas, but it also contained the basic tenets of the Historical School of law. 83

Savigny's rejection of the proposal was founded upon his basic understanding that law should be understood as an aspect of social life, which integrates the complex and unique experiences of a particular nation. By saying this, Savigny countered not only the idea of codification but also the very basic assumption of the Natural law philosophy which assumes that law is universal in its character. 84 There was no such thing as "a self-contained phenomena of collected verbal formulae in some universal body of ideal or "natural' propositions" of law as Thibaut believed. 85 Law should, as Savigny noted, grow 'organically' from its root of the "common consciousness of the people" (volkgeist) through a historical process and not through an instant act of legislation.86 Savigny understood law as having an intimate and unseparated relationship with a particular life experience of people and because of that, the belief that a universal code could be determined was nonsense since law should reflect unique needs and characters of the people of each nation. 87 To summarize his theory, Konrad

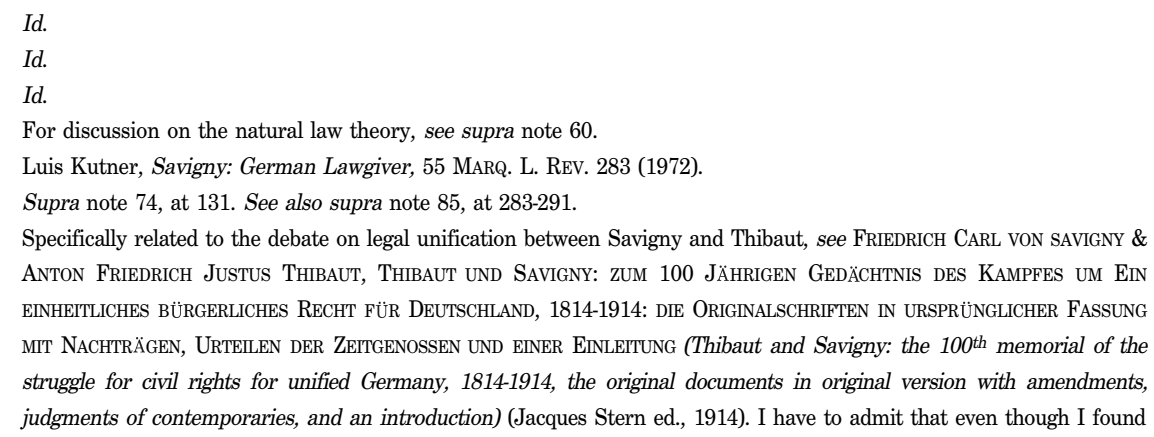
Anton Friedrich Justus Thibaut, Thibaut und SAvigny: zum 100 JÄhrigen Gedächtnis des Kampfes um Ein EINHEITLICHES BÜRGERLICHES RECHT FÜR DEUTSCHLAND, 1814-1914: DIE ORIGINALSCHRIFTEN IN URSPRÜNGLICHER FASSUNG MIT NACHTRÄGEN, URTEILEN DER ZeITGENOSSEN UND EINER EINLEITUNG (Thibaut and Savigny: the 100th memorial of the struggle for civil rights for unified Germany, 1814-1914, the original documents in original version with amendments, judgments of contemporaries, and an introduction) (Jacques Stern ed., 1914). I have to admit that even though I found 
Zweigert and Hein Kotz describe Savigny as follow:

In contrast to the Enlightenment view that the legal order is a deliberately planned purposive creation of an official legislator guided by reason, Savigny and Historical School of Law saw law as a historically determined product of civilization, having its roots deep in the spirit of the people and maturing there in long processes. Like language, poetry and religion, law is the product not of the formative reason of a particular legislator, but an organic growth, rather like a plant, of the "inner secret power" of the "spirit of people" working through history. For the adherents of the Historical School of Law all true law is customary law, developed, handed down and captured in usage and manners; the law-bearers are the people and, as the people's representative, the lawyers. 88

With particular regard to rejecting the proposal of codification, Savigny made two specific arguments. ${ }^{89}$ First, during his contemporary time the "state of public mind" of Germany was not yet mature to step into the codification era. To move hasty into a codification stage without any maturity of political element would only lead to a chaotic situation within society. Savigny argued that the very fundamental function of the state is not to determine a universal formulation of law through a legislative act but rather to discover and enforce customary law. 90 This argument would be echoed around fifty years later by Van Vollenhoven in defending adat law. Second, while the first argument deals with the aspect of social and political ripeness, the second argument points out to the aspect of a juristic maturity. Savigny argued that the codification could not be achieved, even if the political culture is mature enough, unless the juristic maturity of 'technical element' is available to do the task.91 Codification acts reflect the condition of a highly developed study of law. By this developed and mature juristic culture, codified laws would be an accurate reflection of the living laws that grow from the bottom of the spirit of the nation through gradual historical processes. This expertise, Savigny believed, was unavailable at his time.

Thus, from these two arguments we can see that Savigny actually did not reject completely the idea of codification; he only rejected any instant codifications that took place not in the right time and right place due to the lack of both the ripeness of political and juristic culture. For Savigny, codification was a part of a whole historical organic

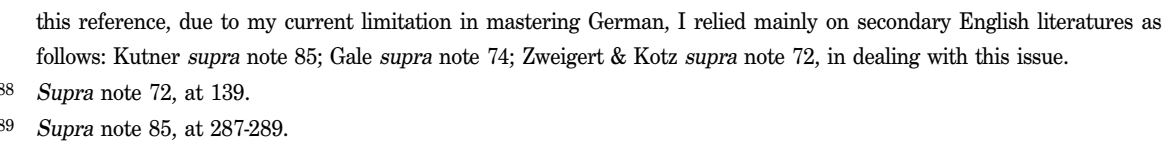


development of a nation that gradually grows from a simple rule of customary law to the more developed system. Codification was a reflection of living law that would grow as a historical consequence of a mature society. Probably due to his outstanding influence overcoming the Thibaut's proposal, Germany did not adopt a civil code until 1896 (came into force in January 1900). 92

Apparently, this historical precedent would be lingering on the bottom of the formulation of adat law theory. Peter Burn has noted this relation in his book, The Leiden Legacy. When Van Vollenhoven had to deal with the study of colonial law, he realized that there were similarities and parallels between the matters in hand with the German legal history. 93

\section{Dutch Academic Position on the Legal Unification}

From the middle ages up to, at least, Savigny's era, Germany had no centralized, structured political and judicial organ. Following the decline of Hohenstaufens (the dynasty of German Kings) in 12th century, the central Germanic power was faded while, consequently, the provincial and local rulers were increasing. Since then, for centuries German did not have a tight centralized power which was important for judicial unification. This situation was in contrast to England and France in which in these two countries' centralized political empires were established. Both England and France had the Royal courts organized by solid lawyer organizations. In contrast, due to the lack of centralized political power, Germany had no German common private law or strong central courts endowed with royal authority. ${ }^{94}$

Similar to the situation in Germany, for centuries, after the decline of relatively centralized power of Majapahit Empire in the fifteenth century, the NEI archipelago was ruled by separate independent sultanates and kingdoms. 95 Every kingdoms and sultanates enforced their own local customary (adat) laws. When Dutchmen came at the first time to the archipelago in the fifteenth century they had to deal with these independent sultanates in relation to, for example, the security and trading agreements. 96 In addition, Hugo Grotius, the greatest Dutch legal scholar, in his Mare Liberum stated that: "Java, Sumatra, the Moluccas have their own kings, public

Id. See also supra note 72 , at 140 .

93 Supra note 43 , at 236 . However, Peter Burn only slightly discussed this matter. Hopefully, this paper can add some information to enrich what Burn has discussed.

94 Supra note 72 , at $134-135$.

95 For an introduction to this history, see, e.g., M. C. Ricklefs, A History of Modern INDONESIA Since C. 1200 3-59 (3rd ed. 2001).

96 G.J. RESINK, INDONESIA's History BETWEen THE MYTH 197 (1968). 
institutions, laws and rights and they have always had them." 97 Dutch occupation of the archipelago a century afterward which had forced almost all sultanates and kingdoms to subjugate, to some extent, was similar to France, under Napoleon, occupation of Germany (and also Netherland) that compelled all the small states of Germany to form the Rhine confederation under Napoleon. Furthermore, despite German principalities having received the Roman law with all different actualities pursuant to the variety of local customs, Napoleon code had united them under a single system during the Rhine era. This fact had met its resemblance in the context of the NEI where before the Dutch occupation every sultanates and kingdoms had, to some extent, made the reception of some aspects of Islamic law with its local interpretations. Dutch law (which in fact was not a genuine Dutch law since it was heavily shaped by both Roman and French Napoleon law) compelled all these sultanates and kingdoms to subjugate under a single system and only left a small room for both Islamic law and adat (custom) to survive.

When Idenburg carried on the dream of Enlightenment by submitting his proposal of the legal unification of the NEI to the parliament, Germanic historical debate on codification found its complete resemblance. Van Vollenhoven, like Von Savigny, reintroduced the counter-Enlightenment arguments. 98 Van Vollenhoven followed his German predecessor in defending customary law (adat) against the intrusion of foreign (Western but also Islamic) law. He exalted custom over codification. He believed that law should grow organically from the root of local culture gradually, from a simple customary law to a more developed legal system. ${ }^{99}$ Introducing or 'transplanting' the Dutch 'hand-made' law would harm the society and brought about the chaotic situation. Dutch law was foreign and had no social and cultural basis for Indonesian people. Because of that, civil code unification would be harmful to the society, Van Vollenhoven alerted, and it would give Islamic law an opportunity to take over the prevailing law in Indonesia.

Supra note 57, at 194. However, I found a different expression. Grotius said this in the context of rejecting Portuguese exclusive claim of access to the East Indies (later Southeast Asia/Indonesian archipelago). Grotius challenged this claim in three constituent points: rejecting Portuguese claim of right of possession, the right of navigation and the right of trade. For Grotius, Portuguese had no claim of possession by virtue of discovery since the East Indies were not terra nullius, but in the possession of their native rulers. "These islands we speak of have, and always had, their kings, their commonwealth, their laws and their liberties." See Hugo GroTIUS, THE FREE SEA XVXVII \& 13-15 (Richad Hakluyt trans., 2004).

98 For this account, see Garry F. Bell, Multiculturalism in Law is Legal Pluralism: Lesson from Indonesia, Singapore and Canada, SING. J. LEGAL STUD. 324 (2006).

99 See Part II.B of this paper (FN 41-47). 


\section{Savigny vs. Vollenhoven}

A major difference between Von Savigny and Van Vollenhoven should be presented here. Savigny's writings are not free from contradictions. While his goal to cultivate law from historical processes of spirit of the German people is clear, his main interest in Roman law to find its purest form through a historical method has led us to confusion. Hermann Klenner called it a contradiction between the theory and methodology of Savigny. 100 His theory, saying that law is a living norm and grows organically from the root of spirit of the people through gradual processes of history, seems to contradict his methodological recipe to investigate and find the purest form of Roman law.101 Savigny, however, had emphasized that studying Roman law was simply a method to help German jurists understand and develop their own law.102 But the contradiction between his theory and method is quite clear, as can be seen from the rise of two frictions within the Historical School of Law. The two frictions between the Romanists and Germanics engaged in a debate concerning the advisability of the Reception of Roman Law.103 Germanic faction's main critics said that the jurist's concern on the investigation of the Roman law had prevented them to contact with their German volk law. German teutonic tradition became alienated and ruined its land due to the preoccupation of the jurists to investigate the "foreign Roman law." 104 Van Vollenhoven was a part of this faction. Apparently, however, he did not want to do the same mistake like Savigny. He defended adat law from the contamination of foreign elements (both the Dutch law and Islamic Sharia law). He received only the insightful theory of Savigny in dealing with the conception of law as a product of an organic development of a nation and put aside Savigny's method. 105

\section{E. Summary}

The author would conclude this part by mentioning a heartbreaking side of the story. Both Savigny and Van Vollenhoven were successful not only in killing the idea of legal codification for their times (Thibaut's proposal in Savigny's era and Idenburg's proposal in Van Vollenhoven's time), but also in establishing the influences afterwards. However, their idea of anti-codification did not last long. After Savigny's retirement, the

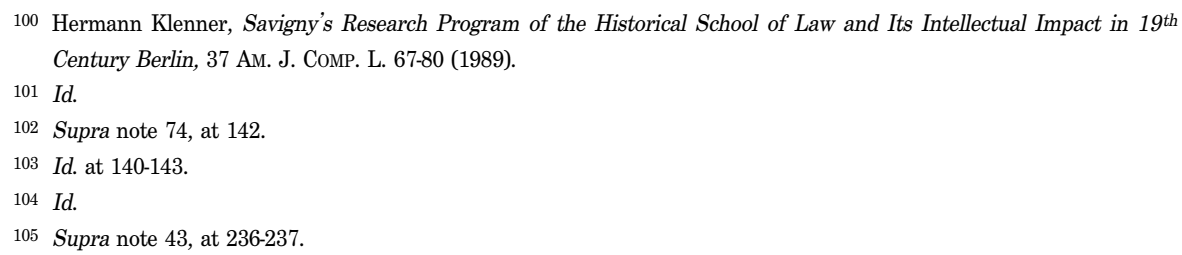


Romanist faction which was identical with Savigny's faction devoted their concern on the systematization of Roman legal axioms by analyzing closely the Digests of Justinian, known also as Pandekten. They attempted to form a "system of classification which would not only aid lawyers in finding the applicable law for a given set of facts, but would also suggest the correct solution to new cases." 106 A border line that separated the Historical School of Law from the Natural law ideas became blurred in the hand of Pendactists. No more than fifteenth years after Savigny's death (1861), triggered by this intellectual development and pragmatic political situations, in 1874, a commission of eleven members, consisting of judges, politicians and legal scholars, were authorized to prepare a draft of German civil code. After several years of debates, this draft was finally adopted on August 18, 1896 and came into force on January 1, 1900.107

Almost similarly, Van Vollenhoven's story followed this path. The killers of his ideal dream of the formulation of a genuinely Indonesian law, tragically, were his Indonesian students who later became the political and intellectual leaders.108 The Dutch colonial legal policy, with a special treatment for adat, remained similar until the last day of the Dutch occupation. After the independence in 1945, Indonesian legal scholars as well as Indonesian founding fathers were in a dilemmatic situation to choose between the unifying Western legal tradition and adat law. Ironically, the former option was in their favor.109 The opposing view of Van Vollenhoven which was ironically highly colonialist, as M.B. Hooker notes, has prevailed in Indonesia after the independence.110 Indeed, the desire for legal unification in Indonesia, as someone has mentioned, had begun to rise since 1928 when a members of the NEI Volksraad (a representative assembly with only an advisory power created by the Dutch) observed that: "The admiration of adat law is to be found more among Europeans than among Indonesians."111 Daniel S. Lev's essay, Judicial Unification in Post-colonial Indonesia extensively discusses the reasons and

106 Supra note 74 , at $144-145$.

107 Id.

108 Supra note 50, at 64.

109 Supra note 48, at 63. See also R. Soerojo Wignjodipoero, S.H, Kedudukan Serta Perkembangan Hukum Adat SETelah KemerdekaAn (The Position And Development of ADAT LAW AFTer IndePendence) 80-82 (1983).

110 M. B. Hooker, Legal Pluralism: An Introduction to Colonial and Neo-Colonial LaW 283 (1975). Although Hazairin himself was an Adat Law professor, he mainly opposed the idea of reception theory in adat law saying that Islamic law could not be applied unless it has been integrated into adat. He said that this kind of theory is 'teori iblis' (theory of the devil). See Hazairin, Hukum Keluarga Nasional (National Family Law) 7-10 (1982). For his strong opposition to Adat Law, see Tujuh Serangkai Tentang Hukum (Seven Series on Law) (1974), \& Pergolakan Penyesuaian Adat Pada Hukum Islam (The Upheaval of Adat Adjustment to Islam) (1952).

111 I. H. Cassutto, Het Adatrecht van Nederlandsch-Indië, zijn Waarde voor het Heden en voor de Toekomst, supra note 48, at 63. The ultimate goal of almost all Indonesian legal scholars is to find the best formulation of national codified law. Adat, which is particular and unique in its nature, was also subjected to a new interpretation to find "universal value of adat law" for national integration through legal unification. See Wignjodipoero, supra note 109, at 40. 
major social and political situation toward the legal unification in Indonesia from the late Dutch colonialism to the post-independent era of Indonesia.112 For Lev, major impetuses to legal unification, not only in Indonesia but also anywhere in post-colonial states, have been ideological and political.113 Immediate reaction against the racial divisive colonial policy as manifested in the Dutch colonial legal system which, in Indonesian context, differentiated unjustly 'civilized' Europeans to 'uncivilized' natives was the desire to abolish it. Unification promised equality among the people. This sentiment met with a situation where the political and intellectual elites were inspired by the promise of modernization and political integration.114 Legal unification in this regard, was a necessary step. Furthermore, politically, legal unification was the main tool to establish political authority over the new State, which was usually unstable and diffuse. Colonialism, as it was in Indonesia, came with separatist and regionalist policy. It not only recognized the existence of tribes and its leaders, but reinforced and separated them. ${ }^{115}$ In the beginning of independence, these local leaders challenge the leadership of the vulnerable and weak new national leaders and they were not voluntary willing to transfer their local authority for the sake of the larger national interests. Thus, without legal unification the dream to unite these fractions politically would be even harder.

\section{Conclusion}

This paper has tried to track adat law discourse down to its motherland origin. The author found that adat law was indeed part of the Romantic legal movement that took place in the late eighteenth century's Europe. It was a counter movement to the prevailing idea of the Enlightenment. In the context of Indonesia, this Romantic view met with pragmatic and political interests of the colonial government. Supporting and promoting adat could help the colonial government to win its competition against Islamic law. Taming Islam in the colony was the best bay to extract and exploit the land for the benefit of the colonial government.

This tracking process has led me not only to the epicenter of classical debate in Europe in relation to the codification issues, but more than that it has illuminated my understanding to the very recent intellectual debate of comparative law, mainly in

\footnotetext{
112 Daniel S. Lev, Judicial Unification in Post-colonial Indonesia, 16 InDONESIA 1-37 (1973).

113 Id.

$114 \mathrm{Id}$.

$115 \mathrm{Id}$.
} 
Europe, in relation to the issue of legal unification of the European Union. By way of conclusion, let me recall very briefly the relevance of our discussion on adat law to comprehend the contemporary debate on whether or not Europe should merge into single legal system.

This recent debate is triggered by the merging of the European market into a single economic block. Following this economic integration, the idea of European legal integration immediately rose into the stage of the European intellectual arena. Some scholars are in favor of the merger, while others are against it. History repeats itself. The arguments that have been utilized by these two contrasting positions, to some extent, are the continuation of the classical debate on legal unification in the late eighteen century of Germany (or probably everywhere). The proponents of European legal unification hold a positivistic stance and become the vanguard of the Enlightenment's dream. On the contrary, as can be predicted, the opponents receive their armors to defend the argument of legal plurality from, partly, the tradition of European legal Romanticism. 116

In relation to the anti-unification position of the EU legal system, James Q. Whitman, in one of his recent essay, The Neo-Romantic Turn, argues that within the last several years, the argument of Romanticism has returned to the philosophy of comparative law.117 In this case, Pierre Legrand has echoed the voice of Romanticism in his strong opposition to the idea of legal unification.118 Influenced so much by Derrida, and also Heidegger, he employs Romantic sentiment using hermeneutic tools to defend differences and plurality against the aggression of the desire of sameness and uniformity. ${ }^{119}$ His main argument in defending legal pluralism is based on his idea of "law as culture." Legrand understands the term as "the framework of intangibles within which an ascertainable 'legal' community operates and which organizes the identity of such legal community as legal community." 120 [Italic added] Thus for him, law always exists within and become a part of specific and unique experience of a particular culture. Because of that, Legrand rejected the possibility of 'legal transplantation' in which a legal system could be easily moved from one place to another. Finally, for him, "European legal system are not converging" at all.121

For the author, what Legrand and other culturalist legal scholars have proposed are intellectually stimulating and morally encouraging. It has brought about a new aroma

\footnotetext{
116 Pierre Legrand declares his position as defender of Counter-Enlightenment. See supra note 7, at 265.

117 James Q. Whitman, The Neo-Romantic Turn, in Legrand \& Munday, supra note 6, at 312.

118 Id.

119 Pierre Legrand, Paradoxically, Derrida, 27 CARDozo L. REv. 631 (2005-2006).

120 Pierre Legrand, Comparative Legal Studies and the Matter of Authenticity, 1 J. CoMP. L. 374 (2006).

121 Pierre Legrand, European Legal Systems are not Converging, 45 INT'L \& CoMP. L. Q. $52-81$ (1996).
} 
where comparative law studies now become richer by the flavor of sensitivity to the diverse human values. However, learning from Savigny's case, and also Van Vollenhoven, the author is concerned that their perspective are politically unconvincing for policy makers. When Europe has been economically integrated, new structures and systems are needed to support this integration. One of the most fundamental and practical elements in restructuring the European system is 'legal unification.' We have to wait whether Legrand and other culturalist legal scholars will be successful to 'kill' the proposal and repeat the two historical precedents, as we have discussed. 